\title{
REPRESENTASI KESANTUNAN BERBAHASA DALAM ROMAN "RUMAH KACA" KARYA PRAMOEDYA ANANTA TOER: KAJIAN SOSIOPRAGMATIK
}

\author{
Yuliani Yusuf \\ Fakultas Pascasarjana-Universitas Jambi \\ Corresponding Author: yulianiyusuf72@.gmail.com
}

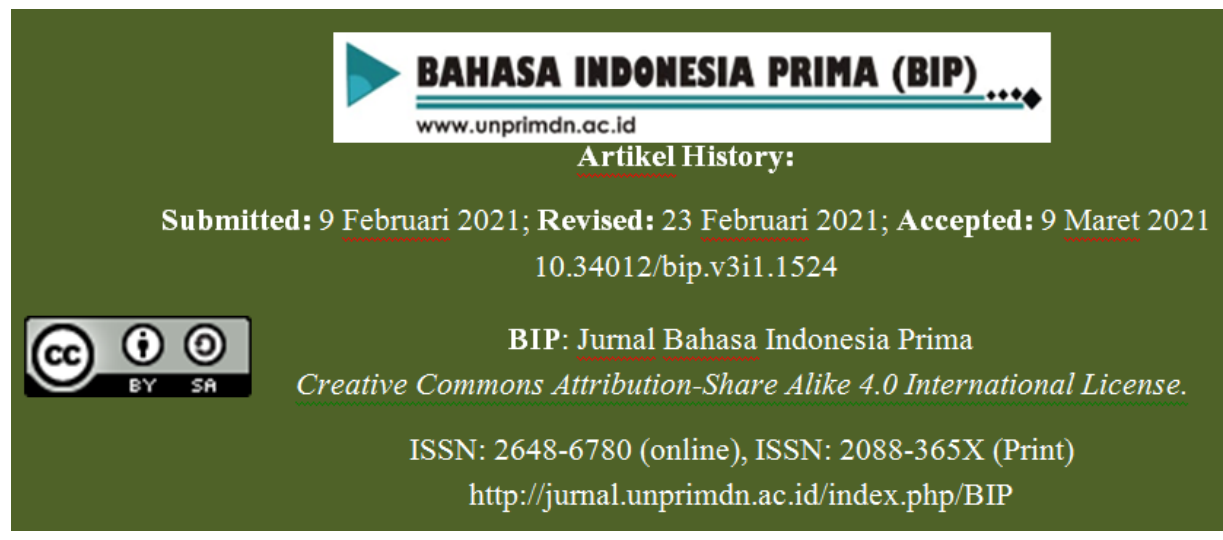

\begin{abstract}
Abstrak-Pendekatan yang digunakan dalam penelitian ini adalah pendekatan kualitatif dengan jenis penelitian deskriptif. Penelitian deskriptif kualitatif dapat diartikan sebagai prosedur pemecahan masalah yang diselidiki dengan menggambarkan dan melukiskan subjek atau objek penelitian pada situasi masyarakat dalam penjajahan Kolonial Belanda tahun 1920-an sesuai hasil kajian studi pustaka. Teknik yang digunakan dalam pengumpulan data adalah teknik baca dan tulis. Analisis data dalam penelitian ini menggunakan teknik analisis studi pustaka pada tuturan tokoh roman dalam kajian sosiopragmatik. Data diperoleh dari tuturan tokoh roman "Rumah Kaca" karya Pramoedya Ananta Toer. Hasil penelitian ini adalah representasi kesantunan berbahasa dalam roman "Rumah Kaca" karya Pramoedya Ananta Toer tergambar dalam bentuk tindak tutur: (a) direktif/kompetitif, yaitu menuntut, memerintah, meminta, memohon, melarang, menolak, dan memberi nasihat; (b) tindak tutur ekspresif tergambar pada tindak tutur mengecam dan menuduh; (c) tindak tutur pertentangan, meliputi tindak tutur menantang dan mengancam. Selain itu, strategi kesantunan yang dipakai penutur dalam tuturannya menggunakan: (a) strategi kesantunan positif, yaitu strategi menggunakan tawaran dan strategi memberi pujian dan (b) strategi kesantunan negatif, yaitu strategi kesantunan menggunakan bentuk tuturan tidak langsung dan strategi meminta maaf.
\end{abstract}

Kata kunci: representasi, kesantunan, berbahasa

\section{A. PENDAhuluan}

Kesantunan berbahasa adalah pertuturan baik yang bisa dirasakan peserta tutur, baik ketika mendengarkan tuturan atau setelah memahami makna tuturan. Kesantunan berbahasa juga merupakan wujud sikap berbahasa antara dua pihak komunikan yang saling harga-menghargai. Saat berkomunikasi, penutur dan petutur tidak hanya dituntut menyampaikan kebenaran, tetapi harus tetap berkomitmen untuk menjaga keharmonisan hubungan. Keharmonisan hubungan penutur dan petutur tetap terjaga apabila masing- masing peserta tutur senantiasa tidak saling mempermalukan.

Sejumlah fakta menunjukkan bahwa tidak setiap peserta tutur mampu menyajikan sebuah tuturan yang santun, baik dilakukan oleh orang-orang yang memiliki status sosial tinggi maupun mereka yang tergolong berpendidikan rendah. Seperti yang dikemukakan Pranowo (dalam Chaer, 2010:4), yaitu Pertama, banyak orang yang secara sosial tergolong level menengah atau atas (seperti anggota DPR), tetapi secara kultural masih tergolong level ini dhupak bujang (kelas bawah). Kedua, 
kemampuan berbahasa secara santun tidak ditentukan oleh pangkat dan jabatan, tetapi ditentukan oleh level budaya seseorang.

Berhubungan dengan kesantunan berbahasa, dilihat dari segi etika berbahasa dalam berinteraksi, Masinambouw (dalam Chaer dan Agustina, 2010:172), mengatakan bahwa sistem bahasa mempunyai fungsi sebagai sarana berlangsungnya interaksi manusia di dalam masyarakat maka berarti di dalam tindak laku berbahasa haruslah disertai dengan norma-norma yang berlaku di dalam budaya itu. Sistem tindak laku berbahasa menurut norma-norma budaya itu disebut etika berbahasa atau tata cara berbahasa.

Koentjaraningrat (dalam Chaer, 2010:8) berpendapat bahwa ada hubungan antara kemampuan bahasa dengan sikap mental para penuturnya. Maka, buruknya kemampuan berbahasa Indonesia sebagian besar orang Indonesia adalah karena adanya sifat-sifat negatif yang melekat pada mental sebagian besar orang Indonesia. Sifat negatif itu adalah (1) suka meremehkan mutu, (2) mental menerabas, (3) tuna harga diri, (4) tidak disiplin, (5) enggan bertanggung jawab, dan (6) suka latah atau ikit-ikutan.

Jadi bisa disimpulkan bahwa siapa pun dan apa pun golongan sosial seseorang, di mana pun berada dan kepada siapa pun berbicara, serta dalam suasana hati bagaimana pun juga, berbicara hendaknya lebih mengedepankan kesantunan dan sikap hargamenghargai sehingga tujuan pertuturan sampai sesuai harapan penutur dan hubungan sosial antarpenutur tetap terjaga dengan baik.

Pada era tahun 1900-an, Indonesia masih merupakan negeri jajahan bangsa Kolonial Belanda. Roman "Rumah Kaca" mengambil setting ceritanya adalah kehidupan di tahun 1900-an. Seperti yang dikemukakan oleh Arif Syaifurrisal bahwa "Tetralogi yang ditulis oleh Pramoedya Ananta Toer ini mengambil latar kebangunan dan cikal bakal sebuah negeri bernama Indonesia di awal abad ke-20: awal tumbuhnya kesadaran dan pergerakan Nasional." Pada masa itu orang-orang berdarah asli Belanda dan keturunan Belanda menempatkan kehormatan dirinya lebih tinggi daripada kaum pribumi atau disebutnya Inlander. Pola pikir feodal masih sangat kuat. Ada pembagian kelas status sosial secara tegas berdasarkan keturunan darah, pangkat, dan jabatan, yang akhirnya dikenal adanya kaum pejabat pemerintahan, kaum bangsawan, kaum terpelajar, kelompok pengusaha, dan pekerja rendahan. Kelompok yang lebih rendah akan bersikap dan bertutur lebih hormat dan santun kepada kelompok di atasnya, demikian sebaliknya. Namun, tidak menutup kemungkinan kelompok dengan status sosial $(\mathrm{S}+)$ dan kekuasaan $(\mathrm{K}+)$ lebih tinggi akan menjaga pertuturan tetap santun kepada pihak dengan status sosial (S-) dan kekuasaan (K-) lebih rendah karena ada kepentingan politik, ekonomi, dan kepentingan kekuasaan yang harus dikedepankan.

Belanda sebagi penjajah mampu bertahun berabad-abad di Indonesia, tentu tidak lepas dari kemampuan berbahasanya. Bagaimana mereka menarik simpati? Bagaimana mereka menekan rasa kepatuhan masyarakat pribumi? Fenomena- fenomena kebahasaan itu perlu ditelaah untuk melihat kesantunan berbahasa kelompok masyarakat pada saat itu.

Peneliti tertarik untuk meneliti kesantunan berbahasa pada tuturan tokoh roman "Rumah Kaca" karena peneliti menganggap representasi kesantunan berbahasa pada masa penjajahan memiliki ciri tersendiri yang berbeda dengan kesantunan berbahasa masyarakat dewasa ini. Keragaman konflik, baik konflik kepentingan individu, konflik kepentingan kelompok, kepentingan kekuasaan, harga diri, ekonomi, dan lainnya akan sangat mempengaruhi kesantunan berbahasa.

\section{B. METODE PENELITIAN}

Penelitian ini merupakan penelitian dalam lingkup fragmatik yang menelaah fenomena bentuk kesantunan berbahasa dan strategi kesantunan berbahasa sekelompok masyarakat yang tergambar pada pertuturan tokoh dalam roman "Rumah Kaca" karya Pramoedya Ananta Toer. Pendekatan dalam penelitian ini adalah kualitatif dan jenis penelitian deskriptif dalam kajian sosiopragmatik. Penelitian deskriptif kualitatif dapat diartikan sebagai prosedur pemecahan masalah yang diteliti dengan menggambarkan atau melukiskan keadaan subjek dan objek penelitian pada situasi di masa pertuturan dalam roman "Rumah Kaca" berlangsung. Dalam penelitian ini merepresentasikan kesantunan tuturan tokoh dalam roman "Rumah Kaca".

Data-data yang ada dideskripsikan juga ditafsirkan berdasarkan konteksnya. Data dalam penelitian ini adalah data verbal. Data 
verbal berwujud tuturan-tuturan kesantunan berbahasa para tokoh dalam roman "Rumah Kaca" yang diperoleh melalui studi pustaka. Sumber data dalam penelitian ini adalah roman "Rumah Kaca" karya Pramoedya Ananta Toer buku cetakan kesembilan, November 2011 oleh penerbit Lentera Dipantara-Jakarta. Teknik pengumpulan data menggunakan lima tahap: 1) teknik baca, memahami makna tuturan tokoh secara tersurat dan tersirat dengan menghubungkan budaya yang melatarbelakangi kehidupan tokoh 2) teknik pengelompokan data berupa data tuturan yang menunjukkan kesantunan dalam roman "Rumah Kaca" ke dalam ilokusi-ilokusi yang diteliti, 3) mereduksi data yang telah dikoleksi, 4) data-data yang telah dikategorikan ditulis di kartu data dan catat, dan 5) dikodifikasi untuk memudahkan peneliti dalam menganalisis data.

Agar memperoleh data yang valid, data dianalisis menggunakan model interaktif. Kegiatan pengumpulan data, penyajian data, reduksi data, dan penarikan simpulan bersifat terus-menerus secara kesinambungan berlangsung secara berurutan sebagai rangkaian kegiatan yang saling berkait sampai data jenuh. Untuk menguji keabsahan data digunakan teknik trianggulasi. Teknik trianggulasi yang dapat digunakan untuk melakukan uji keabsahan data, yaitu (1) teknik sumber, (2) teknik metode, (3) teknik peneliti, (4) teknik teori. Dalam penelitian ini peneliti menggunakan teknik teori untuk uji keabsahan data penelitian.

\section{HASIL PENELITIAN DAN PEMBAHASAN}

Berdasarkan data, hasil penelitian terhadap representasi kesantunan berbahasa dalam tuturan tokoh roman "Rumah Kaca" karya Pramoedya Ananta Toer, terdapat 3 bentuk kesantunan tindak tutur, yaitu (1) tindak tutur direktif yang meliputi menuntut, memerintah, meminta, memohon, melarang, menolak, dan memberi nasihat, (2) tindak tutur ekspresif tergambar pada tindak tutur mengecam dan menuduh, dan (3) tindak tutur pertentangan, meliputi tindak tutur menantang dan mengancam. Sedangkan strategi kesantunan yang pada umumnya dipaka dalam tuturan antartokoh ada 2 strategi, yaitu startegi kesantunan positif dan negatif. Strategi kesantunan positif menggunakan bentuk strategi menggunakan tawaran dan strategi memberi pujian. Startegi kesantunan negatif menggunakan bentuk strategi tuturan tidak langsung dan strategi meminta maaf.

\section{a. Representasi kesantunan berbahasa dalam tuturan tokoh roman "Rumah Kaca"}

\section{1) Representasi kesantunan berbahasa pada tindak tutur direktif}

\section{Menuntut}

Tindak tutur menuntut mengakibatkan salah satu pihak merasa dirugikan. Penutur $(n)$ tidak membiarkan petutur ( $t$ ) bebas melakukan sesuatu bahkan memaksa $t$ berbuat sesuatu. Petutur terindikasi melakukan keterpaksaan memenuhi isi tuntutan penutur. Supaya tindak ilokusi menuntut menjadi lebih sopan maka $n$ bisa menggunakan tuturan tidak langsung dengan pilihan kata yang dianggap lebih sopan untuk mengurangi ketidakharmonisan hubungan peserta tutur dan menjaga muka $t$. Contoh:

\section{Wacana 1:}

[1] A: "Pulang," jawabku masih sengit.

[2] B: "Aku tak kan bisa bekerja sendiri tanpa Tuan."

\section{Wacana 2}

[3] A: "Masa cutiku, Tuan, sampai sekarang tidak ada kabar beritanya."

[4] B: "Justru pekerjaan menjadi banyak. Masyarakat Pribumi sudah mulai berubah, Tuan Pangemanann, tidak seperti lima tahun yang lalu."

\section{Memerintah}

Tindak tutur memerintah mengakibatkan mitra tutur merasa dirugikan. penutur menempatkan diri sebagai superior atau memiliki kekuasaan lebih atas diri petutur. Petutur terindikasi melakukan keterpaksaan atau memang secara ikhlas memenuhi perintah penutur. Supaya tindak ilokusi memerintah menjadi lebih sopan maka $n$ bisa menggunakan bentuk tuturan tidak langsung, seperti bertanya, memberitakan, menginformasikan, dan pilihan kata yang dianggap lebih sopan untuk mengurangi ketidakharmonisan hubungan peserta tutur dan menjaga muka $t$. Hal tersebut tergambar dari contoh percakapan berikut:

\section{Wacana 6}

[15] A: "Sourhof," peranakan itu memperkenalkan dirinya dengan suara angkuh.

[16] B: "Tuan tentu akan bisa bekerja sama 
dengan Tuan Sourhof," kata komandanku, kemudian meninggalkan restoran.

\section{Wacana 7}

[17] A: "Tuan De Man, ini Tuan Pangemanann. Harap Tuan layani sepatutnya. Selamat bekerja Tuan Pangemanann.

[18] B: "Tapi, Tuan L," aku menyela, "Apa semua berkas ini harus dibaca disini?"

[19] A: "Benar, Tuan, dokumen-dokumen ini tidak boleh meninggalkan gedung ini, maafkan kami. Tuan harus pelajari semua itu di sini."

\section{Meminta}

Tindak ilokusi meminta menguntungkan $n$ dan merugikan $t$ karena itu ilokusi meminta ada kemungkinan untuk mengancam "muka" $t$. Dalam hal ini $n$ meminta $t$ melakukan sesuatu yang sesuai dengan keinginan $n$. Untuk menunjukkan kesantunan, pada ilokusi meminta, $n$ tidak menunjukkan kekuasaannya secara berlebih kepada $t$. Tuturan cenderung seperti nasihat dan tidak begitu memaksa pada t. Contoh :

\section{Wacana 12}

[29] A: "Maafkan aku, Jacques, aku tidak mampu memenuhi segala kebutuhanmu. Izinkan aku pulang. Aku masih merasa beruntung dapat melihat kau dalam sisa-sisa kebaikanmu, belum seluruhnya rusak."

[30] B: "Jangan, jangan biarkan aku seorang diri."

\section{Wacana 13}

[31] A: "Sudah makan di luar tadi?"

[32] B: "Sudah, sayang. Maafkan," jawabku.

\section{Memohon}

Dalam ilokusi memohon $n$ mengharapkan $t$ melakukan sesuatu untuknya dengan harapan yang sangat besar untuk dikabulkan. Pada ilokusi memohon tingkat kerugian $t$ semakin tinggi daripada ilokusi meminta. Berikut contoh ilokusi memohon:

\section{Wacana 15}

[38] A: "Tuan Pangemanann, sudikah Tuan menceritakan sekedarnya padaku Tentang sejarah Boedi Moeljo?" "Maaf, Tuan, mungkin suatu permintaan yang berlebihlebihan. Tentu saja Tuan bukan saja hanya sekedar tahu malah lebih maklum daripada orang-orang Boedi Moeljo sendiri, malahan tentu saja menguasai sejarah organisasiorganisasi selebihnya."

[39] B: "Sedikit, Tuan," jawabku dalam Belanda.

[40] A: "Sudikah Tuan berbahasa Inggris kepadaku?"

\section{Wacana 16}

[41] A: "Relakan kami pergi."

[42] B: "Nederland sendiri belum menentu nasibnya."

[43] A: "Relakan kami berangkat. Cuma itu yang aku harapkan."

\section{Melarang}

Tindak ilokusi melarang tidak menimbulkan keuntungan pada $n$, tetapi sangat merugikan pada $t$. Implikasi ilokusi ini memaksa $t$ melakukan sesuatu yang tidak diinginkan, tentu hal ini bisa mengancam muka $t$. Kesantunan perlu dipakai jika ada tindak tutur yang berpotensi mengancan muka. Seperti pada contoh berikut ini.

\section{Wacana 20}

[56] A: "Jangan teruskan minum, sayang. Makin lama kau makin banyak minum. Di rumah ini saja kau sudah lima kali mabok. Kasihanilah anak- anakmu. Jangan kau beri contoh seperti itu." Suaranya sayu, matanya juga sayu.

[57] B: "Lupakan, sayang," kataku.

[58] A: "Hentikan minum, Jacques, kembalilah seperti Jacques yang kukenal dan selalu kukenal dan kurindukan dulu. Aku pilih kau, aku cinta kau, Jacques, karena kau punya kelebihan dari orang Prancis pada umumnya."

\section{Menolak}

Tindakan menolak pada representasi kesantunan ini adalah ujaran yang menandakan salah satu peserta tutur tidak berkeinginan melakukan apa yang menjadi kehendak mitra tuturnya. Ilokusi menolak biasanya mengakibatkan dampak tidak menyenangkan. Oleh karena itu, untuk menciptakan kesantunan berbahasa dalam menolak $n$ atau $t$ bisa menggunakan kesantunan negatif dan berbagai indikator kesantunan, seperti penggunaan diksi 'maaf', 'sebenarnya saya belum...', 'kalau bisa ...', dan lainnya. Bisa juga menciptakan suasana yang menyenangkan, adanya alternatif pilihan jawaban, dan mengedepankan rasa persahabatan. Contoh:

\section{Wacana 21}

[59] A: "Dan Paman tentu takkan keberatan menjadi pelindung."

[60] B: "Tentang itu tentu harus aku pikirkan. Orang tua seperti aku tentu harus lebih berhati-hati, harus tahu betul bagaimana ikatan peraturan- peraturan pada diriku 
sebagai pejabat Gubermen.” Mereka Nampak kecewa.

\section{Member nasihat}

Ilokusi memberi nasihat ini berpotensi mengancam 'muka' mitra tutur. Oleh karena itu, $n$ bisa menggunakan bentuk kesantunan negatif dan indikator kesantunan yang lain sehingga tidak ada yang merasa dirugikan atau dipersalahkan dalam pertuturan. Berikut contohnya:

\section{Wacana 24}

[67] A: "Bukan, bukan karena Paman atau Dokter Roemengan atau Advokad Pangkey, maka orang kita akan mendirikan organisasi. Tak perlu anggota yang hanya ikut-ikutan. Apa gunanya? Sebaiknya dibentuk di antara orang-orang yang benar merasakan keperluannya dan mau bekerja untuk organisasi.",

[68] B: "Boleh jadi itu ada benarnya. Tetapi anggota yang tidak mempunyai kebutuhan pun paling tidak bisa bercerita pada temantemannya," selaku.

2) Reprentasi kesantunan berbahasa dalam tindak tutur ekspresif

\section{Mengecam}

Ilokusi mengecam, menantang, menuduh, dan mengancam merupakan bagian dari klasifikasi ekspresif yang tidak menyenangkan. Namun, karena keinginan untuk tetap bersikap santun maka tuturan yang sebenarnya tidak santun itu disampaikan sedemikian rupa sehingga terdengar lebih santun dan ada keinginan $\mathrm{N}$ untuk mengurangi ancaman 'muka' mitra tuturnya. Biasanya tuturan disampaikan dengan tuturan bernada ironi atau Strategi Sindiran. Contoh:

\section{Wacana 28}

[82] A:"Nah, Tuan sudah mendengarkan dengan saksi dua orang pembesar polisi ini. Artinya, kami menganggap Tuan sudah mengetahuinya,"

[83] B: "Janji untuk tidak mencampuri politik dan organisasi," desisnya tak acuh.

"Indah sekali. Seperti komedi bangsawan. Tuan-Tuan pernah lihat komedi bangsawan?" Ia menatap kami seorang demi seorang. "Maksudnya hanya Gubermen saja yang boleh berpolitik dan berorganisasi."

\section{Menuduh}

Ilokusi menuduh berpotensi besar merugikan $t$ dan mengancam 'muka' $t$. Apabila $n$ menuduh t atau pihak lain, berarti $n$ sudah yakin bahwa $t$ atau pihak lain telah berbuat buruk atau melakukan perbuatan melanggar hukum. Untuk mengurangi ketidakharmonisan hubungan $n$ dengan $t$, tuduhan bisa disampaikan menggunakan prinsip ironi, sindiran, atau pernyataan tak langsung. Berikut contoh ilokusi menuduh: Wacana 29

[84] A: "Tuan Direktur yang sekarang serba sebaliknya daripada Tuan Van Aberon."

[85] B: "Maksud Tuan tidak ada perhatian pada pekerjaan Departemennya sendiri?'"

3) Representasi kesantunan berbahasa pada tindak tutur pertentangan

\section{Menantang}

Tindak ilokusi menantang tidak berhubungan dengan kesopanan karena tujuannya memang untuk menimbulkan keributan atau kemarahan mitra tutur sehingga mereka terlibat dalam keributan dan permusuhan. Hanya saja dalam penelitian ini tuturan dengan ilokusi menantang disampaikan dengan menggunakan parameter dan indikator kesantunan berbahasa. Contoh:

\section{Wacana 32}

[93] A: "Apakah Tuan tidak ada pikiran untuk mengembalikan aku ke pasukan seperti dulu? " tanyaku menantang penurunan pangkat.

[94] B: "Akan ada masanya," jawabnya.

\section{Mengancam}

Tuturan pada ilokusi mengancam merupakan perwujudan ekspresi tidak menyenangkan dan menunjukkan fungsi pertentangan. Tentu tidak mengindahkan kesantunan. Namun, karena keinginan $n$ untuk tetap bersikap santun maka tuturan yang sebenarnya tidak santun itu disampaikan dengan pilihan diksi yang lebih santun, mengurangi ketidakharmonisan, dan ketidaksimpatisan karena ada keinginan $n$ untuk mengurangi ancaman 'muka' mitra tuturnya. Contoh:

\section{Wacana 36}

[111] A: "Tuan tinggal di sini barang lima menit, baru kemudian Tuan bisa Pergi dengan aman. Lima menit, Tuan, jangan lupa." Suaranya turun jadi bisikan, "Kalau sebelum itu Tuan sudah berangkat, keselamatan Tuan tidak terjamin."

b. Strategi kesantunan berbahasa dalam roman "Rumah Kaca"

1) Bentuk Strategi kesantunan positif 1. Strategi menggunakan tawaran Strategi memberi tawaran termasuk 
kategori kesantunan positif karena dengan memberi tawaran kita berusaha bersikap baik pada pihak lain tanpa merugikan status dirinya. Strategi menawarkan digunakan untuk meminimalkan paksaan terhadap mitra tutur. Dalam kesantunan positif, $n$ berusaha apa yang dilakukannya dan dimilikinya, atau apa yang merupakan nilai-nilai yang diyakininya, diakui orang lain sebagai sesuatu hal yang baik, menyenangkan, dan patut dihargai. Dengan strategi ini, diharapkan suasana pertuturan menjadi santai dan tidak memojokkan salah satu pihak. Contoh:

\section{Wacana 37}

[113] B: "Selamat datang, Tuan, semoga senang bekerja di sini. Barangkali ada sesuatu yang harus kekerjakan untuk Tuan?"

[114] A: "Belum, Tuan, mungkin lain kali. Ah, mungkin juga ada: tahu Frits Doertier?

Doertier?

\section{Wacana 38}

[115] A: "Sudah lama tidak kelihatan, Tuan Komisaris. Senang sekali hati ini Tuan suka duduk di tempat ini. Apakah sudah memerlukan arak widungan, Tuan Komisaris? Sekali-kali mencoba tidak ada jeleknya, Tuan. Tuan tidak pernah mencoba, tidak percaya?"

\section{Strategi memberi pujian}

Memberi pujian merupakan salah satu strategi yang termasuk dalam kesantunan positif. Dengan memuji, penutur telah memberi perhatian dan rasa simpati atas suatu kebaikan atau kelebihan kepada mitra tuturnya. Pujian yang tulus dan sebenar-benarnya pujian tentu terlihat sebagai kesantunan dalam tuturan. Contoh:

[121] A: "Jangan gusar." Komisaris Besar berlunak-lunak. "Pekerjaan ini memang sungguh baru dalam tugas Kepolisisan Hindia. Para atasan sepenuhnya menyetujui tulisan Tuan. Bukan sekedar menyetujui.

Menghargai! Tuan tak perlu berkecil hati. Orang menilai Tuan sebagai satu-satunya pejabat yang mempunyai pengertian, pengenalan, pengetahuan pemikiran, tentang gejala-gejala baru di Hindia. Hanya Tuan yang bisa menarik kesimpulan dan memberikan saran. Di hadapan Tuan jelas terbentang karier, terang dan gilang-gemilang ... Ya, satu- satunya, dan Tuan seorang."

\section{Wacana 41}

[124] B: "Mereka tak perlu dilampaui, Tuan Pangemanann, mereka guru-guru klasik yang tetap hidup. Pada suatu kali, kalau bangsa
Jawa sudah mengerti terima kasih, mereka akan mematungkan dua penyuluh Jawa tersebut."

[125] A: "Juga akan mematungkan Tuan," Tambahku.

[126]B: "Puji-pujian yang terlalu tinggi, Tuan. Aku bukan pelopor. Paling banyak penyempurna. Raffles dan Veth tetap abadi dalam bidang ini."

2) Bentuk strategi kesantunan negatif 1. Strategi tuturan tidak langsung

Tuturan tidak langsung dapat diartikan sebagai pernyataan yang tidak memiliki hubungan langsung antara pertanyaan dengan jawaban, atau antara pernyataan satu tidak tersambung secara gayut oleh pernyataan selanjutnya. Hubungan kedua kalimat itu harus dimaknai secara lebih jauh lagi melalui analisis dan telaah sesuatu yang masih berhubungan, disesuaikan dengan konteks kalimat. Hal ini bertujuan untuk mengurangi ketidakharmonisan dan tingkat ancaman terhadap ' $m u k a$ ' $n$ atau $t$. Contoh:

\section{Wacana 43}

[133] A: "Menyusun kertas nampaknya lebih mudah daripada mempraktikkan."

[134] B: "Tuan dapat mencoba sendiri menyusun kertas, Tuan," jawabku agak sengit dan aku tahu kata-katanya disemburkan kepadaku bukan sebagai Komisaris, tetapi sebagai peranakan yang terlalu tinggi jabatan.

[135] A: "Sekiranya aku pernah duduk beberapa tahun di Sorbonne ... “

Bentuk strategi tuturan tidak langsung tergambar pada tuturan [133] dan [135], yaitu $n$ berusaha mengecam mitra tuturnya. Namun, $n$ tidak menggunakan kata yang secara harfiah bermakna kegagalan, kebodohan, dan ketidakberesan yang langsung bermakna sindiran atau kecaman. Penutur memilih strategi penuturan tidak langsung, seperti pada tuturan: "Menyusun kertas nampaknya lebih mudah daripada mempraktikkan." Dilanjutkan, "Sekiranya aku pernah duduk beberapa tahun di Sorbonne ... ."

\section{Wacana 44}

[137] A: "Tambahan ranjau-waktu. Kan itu penamaan Tuan sendiri?"

[138] B: "Tidak salah,” jawabku. "Pekerjaan memang belum lagi sepenuhnya selesai."

[139] A: "Bukan sudah selesai atau belum selesai. Soalnya, makin lama Tuan makin nampak tidak yakin pada kertas Tuan sendiri." 
Bentuk strategi tuturan tidak langsung tergambar pada tuturan $n$ yang bermaksud menuduh mitra tuturnya. Untuk menunjukkan kesantunan dan mengurangi ketidakharmonisan antarsesama pejabat tinggi di Kepolisian Betawi, $n$ tidak menggunakan kata yang secara harfiah bermakna perintah, kegagalan, kecerobohan, dan ketidakseriusan. Penutur memilih strategi penuturan tidak langsung, seperti pada tuturan "Bukan sudah selesai atau belum selesai. Soalnya, makin lama Tuan makin nampak tidak yakin pada kertas Tuan sendiri."

\section{Strategi Meminta Maaf}

Meminta maaf merupakan strategi kesantunan negatif karena $n$ memberi beban kepada $t$ untuk memberikan maafnya atau tidak atas perlakuan $n$ yang dianggap kurang pantas dan kurang baik di mata $t$. Dengan Pemakaian strategi meminta maaf, $n$ bermaksud menjaga hubungan baik antara penutur dengan mitra tutur. Contoh:

\section{Wacana 47}

[149] A: "Sungguh-sungguh aku menyesal telah terjadi peristiwa ini, Tuan R.,"

kataku

[150] B: "Di kepolisisan takkan terjadi semacam ini, Tuan Pangemanann. Aku pun sangat menyesal. Sayang sekali Tuan bukan seorang polisi lagi."

Untuk tetap menjaga hubungan yang baik, $n$ menerapkan strategi kesantuan meminta maaf dengan merugikan muka sendiri karena telah merugikan mitra tuturnya dalam menjaga segala kerahasiaan, kehormatan, dan ketenangan dikantor Algemeene Secretarie, dengan tuturan:

"Sungguh-sungguh aku menyesal telah terjadi peristiwa ini, Tuan R."

Pada strategi ini, $\mathrm{n}$ menempatkan dirinya dalam posisi merendahkan diri kepada $t$ karena $n$ merasa telah melakukan perbuatan yang membuat $t$ merasa dirugikan. Untuk itu, $n$ meminta maaf dengan harapan dapat tetap menjalin hubungan yang harmonis dengan $t$.

\section{Wacana 48}

[153] A: "Tuan pangemanann, mari kita lupakan perselisihan kita," katanya.

[154] B: "Tidak ada perselisihan dari pihakku, Tuan," jawabku.

[145] A: "Itu lebih baik lagi," sambungnya.

Tentu meminta maaf kepada bawahan bukan watak asli kolonial. Pada tuturan [153] terlihat strategi meminta maaf yang dilakukan $n$ dengan merugikan dirinya sendiri di hadapan $t$ untuk menunjukkan kesopanan tuturan yang selama ini dirasakan ada ketegangan. Terlihat pada tuturan:

"Tuan pangemanann, mari kita lupakan perselisihan kita," katanya.

\section{SIMPULAN}

Berdasarkan hasil penelitian dan pembahasan yang telah dilakukan dapat diambil kesimpulan sebagai berikut:

a. Representasi kesantunan berbahasa dalam tuturan tokoh roman "Rumah Kaca" ditemukan petunjuk bahwa terdapat beberapa tindak tutur. Tindak tutur yang memiliki fungsi ilokusi kompetitif yang seiring dengan kategori direktif terdapat tujuh tindak ilokusi, diantaranya: (a) tindak ilokusi menuntut, (b) tindak ilokusi memerintah, (c) tindak ilokusi meminta, (d) tindak ilokusi memohon, (e) tindak ilokusi menolak, (f) tindak ilokusi melarang, dan (g) tindak ilokusi memberi nasihat. Sedangkan tindak tutur pada klasifikasi tindak ilokusi ekspresif yang sejalan dengan fungsi ilokusi pertentangan ditemukan empat tindak ilokusi yang diamati, diantaranya: (h) tindak ilokusi mengecam, (i) tindak ilokusi menantang, (j) tindak ilokusi menuduh, dan (k) tindak ilokusi mengancam. Dari hasil penelitian kesantunan tindak tutur yang paling banyak didapat pada fungsi ilokusi kompetitif yang seiring dengan kategori direktif.

b. Strategi kesantunan berbahasa yang tergambar pada tuturan para tokoh roman

"Rumah Kaca" yaitu menggunakan bentuk strategi kesantunan positif, yaitu dengan strategi menggunakan tawaran dan strategi memberi pujian. Juga menggunakan bentuk strategi keantunan negatif, yaitu strategi tutran tidak langsung dan strategi meminta maaf.

Berdasarkan hasil penelitian dan pembahasan yang telah dilakukan didaptkan saran sebagai berikut:

1. Sebagai penutur bahasa, seseorang harus mampu menjaga nilai-nilai berbahasanya sesuai dengan norma-norma yang berlaku pada masa itu, dalam upayanya menyelamatkan muka dan menyelamatkan unsur-unsur kepentingan pribadi dan kepentingan lainnya. Hal 
inilah yang mengakibatkan berkembangannya kesantunan berbahasa, baik kesantunan positif maupun kesantunan negatif antarpeserta tutur. Kesantunan berbahasa seperti ini perlu dihidupkan kembali di tengah-tengan masyarakat masa kini untuk meningkatkan derajat kesantunan berbahasa sekaligus sikap perilaku masyarakat dewasa ini yang cenderung mengalami degradasi moral.

2. Pembelajaran bahasa di sekolah-sekolah hendaknya juga membahas budaya tutur dalam kesantunan berbahasa sehingga siswa terbiasa berbahasa atau bertutur secara santun dan beretika untuk meningkatkan martabat dan citra dirinya.

3. Dalam rangka menanamkan nilai-nilai kesantunan dalam berbahasa, guru dan orang tua dapat menggunakan karya sastra prosa dengan setting waktu 1910an (masa Kolonial) karena penyajian tuturan para tokohnya masih berkecenderungan memenuhi kaidah kebahasaan secara lengkap, banyak menggunakan strategi kesantunan dalam bertutur, seperti tuturan tidak langsung untuk membuat pernyataan yang kurang menyenangkan atau kurang santun menjadi lebih santun sehingga bisa menjaga kehormatan dan keharmonisan dalam pergaulan.

\section{DAFTAR RUJUKAN}

Anonim. 2014. Pedoman Penulisan Tesis; PSMPBSI. Jambi: FKIP- Universitas Negeri Jambi.

Arikunto, Suharsimi. 2013. Prosedur Penelitian; Suatu Pendekatan Praktik. Jakarta: Rineka cipta.

Aziz, Aminudin. 2012. Diakses 24 Des 2015. Merumuskan - prinsip-kesantunanberbahasa-dalam-masyarakat-indonesia. http://aminudin.staf.upi.edu.

Biografi: Pramoedya Ananta Toer Diakses tanggal 5 Maret 2015. http://santriscientist.blogspot.com/2013/ 05/biografi-pramoedya-ananta toer_3655.html.

Brown, Gillian dan Yule, George. 1996.
Analisis Wacana. Jakarta: Gramedia. Chaer, Abdul. 2010. Kesantunan Berbahasa. Jakarta: Rineka Cipta.

2010. Sosiolinguistik: Perkenalan awal. Jakarta: Rineka Cipta.

Cummings, Louise. 2007. Pragmatik: Sebuah Perspektif Multidisipliner; Terjemahan Eti Setiawati, dkk. Yogyakarta: Pustaka Pelajar.

Darma, Yoce Aliah. 2009. Analisis Wacana Kritis. Bandung:Yrama Widya.

Fajri, Em Zul dan Ratu Aprilia Senja. Edisi Revisi. Kamus Lengkap Bahasa Indonesia. Indonesia: Diva Publisher.

Ibrahim, Syukur. 1992. Kajian Tindak Tutur. Surabaya: Usaha Nasional. Indrawan, Rully dan R. Poppy Yaniawati. 2014. Metodologi Penelitian: Kuantitatif, Kualitatif, dan Campuran. Bandung: Refikan-Aditama.

Ismawati, Esti. 2011. Metode Penelitian Pendidikan Bahasa dan sastra. Surakarta: Yuma pustaka.

Ismawati, Esti. 2013. Pengajaran Sastra. Yogyakarta: Penerbit Ombak.

Kuntarto, Eko. 1999. Strategi Kesantunan Dwibahasawan Indonesia-Jawa Kajian pada Wacana Lisan Bahasa Indonesia, Disertasi. IKIP Malang, Program Pascasarjana Program Studi Pendidikan Bahasa. Malang.

Leech, Geoffrey. 1993. Prinsip-prinsip Pragmatik; Terjemahan MDD Oka, M.A. Jakarta: UI. PRESS.

M.S., Mahsun. 2014. Metode Penelitian Bahasa: Tahapan Strategi, Metode, dan Tekniknya; edisi Revisi. Jakarta: Rajawali Pers.

Nadar, X.F. 2008. Pragmatik Penelitian Pragmatik. Yogyakarta: Graha Ilmu. 
Nurcahyani, Nani. 2008. Anasir-anasir feminisme dalam dua novel trilogi pulau buru karya pramoedya ananta toer, Tesis. Universitas Indonesia, Depok.

Nurhayati. 2010. Realisasi kesantunan berbahasa dalam novel ronggeng dukuh paruk karya ahmad tohari, Tesis. Universitas Sebelas Maret. Surakarta.

Nurhayati, Neng. 2014. Strategi Kesantunan Imperatif Percakapan Dosen dan Mahasiswa di STKIP Siliwangi Bandung: Kajian Pragmatik, Tesis. STKIP Siliwangi. Bandung.

Oktaviana, K., Diakses 22 Desember 2014. Kajian Teori; Kesantunan Berbahasa. Eprints.uny.ac.id.

Pranowo. 2012. Berbahasa secara santun. Yogyakarta: Pustaka Pelajar. Purwanti, Yuni. 2009. Novel Saman dan larung Karya Ayu Utami dalam Perspektif Gender, Tesis. Universitas Sebelas Maret. Surakarta.

Rahardi, Kunjana. 2005. Pragmatik Kesantunan Imperatif Bahasa Indonesia. Jakarta: Erlangga.

Rahardi, Kunjana. 2009. Sosiopragmatik. Jakarta: Erlangga. Sudrajat, Yayat. 2011. Makna Dalam Wacana. Bandung: Yrama Widya. Sugiyono. 2013. Metode Penelitian Pendidikan; pendekatan kuantitatif, kualitatif, dan $R$ \& $D$. Bandung: Alfabeta.

Tarigan, Henry Guntur. 1986. Pengajaran Pragmatik. Bandung: Angkasa.

Tetralogi Buru https://www.kompasiqna.com/arif.syaif urrisal/552a99f17e61dd26d62459/ tetralogi_pulau_sebuah_konfirmasi_seja rahTetralogi Pulau Buru: Sebuah Konfirmasi Sejarah hhps://id.wikipedia.org/wiki/Tetralogi_ Buru

Wijana, Putu Dewa, I. 1996. Dasar-dasar Pragmatik. Yogyakarta: Andi. Wiryotinoyo, Mujiyono. 2013.
Implikatur Percakapan Anak Usia Sekolah Dasar. Malang: UM Press. 